\title{
ESOTERICISM AND SECRECY IN ALTERNATIVE LITERARY HISTORIES
}

The academic field of esotericism has been structured by the research on the marginal domains of religion and philosophy, like astrology, alchemy, Gnosticism, the hermetic disciplines, the Kabbalah, the secret societies, the Rosicrucian practices or theosophy, aiming to crystallize an interdisciplinary domain whose main discourse exploits transversally philosophy, art, literature, the socio-human sciences as well as the history of religions and the consumer culture, in order to delineate a so-called "repudiated knowledge" (the term belongs to Wouter J. Hanegraaff, probably the best European specialist in the field nowadays), namely a type of knowledge which challenges the mainstream philosophical and religious discourses but it's obviously difficult to ignore on the cultural stage of the recent decades. Due to its multifaced expressions, esotericism ends by becoming a more or less volatile and methodologically difficult domain, prone to being structured and systematized by several devoted scholars.

Promoted in the French academic milieu of the 1950s, the so-called scholarly esotericism (ésotérisme savant) openly targets the scientific objectivity of the field by identifying and deciphering in a systematic way the sub-textual, hidden or openly esoteric references of different literary texts. The champions of this effort of bringing together under the same umbrella a heretic discipline like esotericism and the history literature are Robert Amadou and Robert Kanters, who have had several works published so far, besides co-authoring a seminal anthology entitled Anthologie littéraire de l'occultisme. By taking into consideration several esoteric disciplines like astrology, alchemy and theosophy, Robert Amadou ${ }^{1}$ proposes a general theory of esotericism, conceived as a cluster of hybrid doctrines and practices based on the assumption that all the objects of the assemblage are linked together by necessary, intentional, non-temporal and non-spatial relationships. Actually, the author is driven by the old thesis of the universal correspondences existing all over the world, which he uses to scrutinize literature from an esoteric point of view.

Amalgamating discourses of secrecy, philosophy and literature, the emergence of French scholarly esotericism is also accompanied by the strong tendency to scientifically legitimize the popular level of esotericism. The work that manages to conciliate both the scholarly and the popular halves of esotericism is Louis Pauwels and Jacques Bergier's The Morning of the Magicians (1960), in which the authors

\footnotetext{
1 See Pierre Lagrange, Renaissance d'un ésotérisme occidental (1945-1960): L'ésotérisme contemporain et ses lecteurs: Entre savoirs, croyances et fictions [en ligne], Paris: Éditions de la Bibliothèque publique d'information, 2005. Accesed August $3^{\text {rd }} 2017$.
}

DACOROMANIA LITTERARIA, VI, 2019, pp. 47-57 
openly mix science and popular esotericism, together with an effort to provide valid keys for understanding the secrecies existing inside our modern world.

Antoine Faivre, a professor at the École Pratique des Hautes Études (Sorbonnne) conceives esotericism as a special „form of thinking”" and makes an inventory of its assets, classified by the author into five main orientations ${ }^{3}$, each characterized by variables and fluctuations. The first one of them, „esotericism understood as a heterogeneous assemblage", lists under the umbrella of the domain any production marked by mystery, which outlines a rather shadowy territory governed by an infinity of crisscrossed symbolic relationships and including practically everything from images and themes to motifs and symbols. Obviously, such a generous, if not vague, opening requires a strict methodological constraint, obtained by Faivre by limiting the domain to phenomena delineated by secrecy and initiation. This brings forth the second orientation, that is esotericism as a set of "teachings and facts deliberately hidden", which equals esotericism with initiation. This is an equation which, on the one hand, easily concedes to the thesis of conspiracy, fuelling all sorts of literary myths, and, on the other, suggests that secrecy is universal and ubiquitous, that there are hidden meanings even in the smallest things of the world, which does not seem to be entirely true since, despite its etymological meaning, esotericism may manifest itself as facts, items and messages which go well beyond secrecy itself and are openly heralded as "exoteric".

The third dimension of esotericism suggested by Faivre lies not far from the connection established by secrecy requires initiation, and is emphasised by targeting a mystery "inherent to anything that exists". Antoine Faivre defines it by saying that it is almost common knowledge and a universally accepted cultural fact that reality is offered to us as something hidden by its very nature. Thus, not only is nature oversaturated by occult "signatures", but the history of humanity is also "hidden", but not because those who have written it have deliberately omitted any events, but because history contains in itself messages and signs which become accessible only to a historian who has been initiated.

Initiation is also essential in the next dimension identified by Faivre, which is the "Gnosis", a type of knowledge embedded in the myth and the symbol, both conceived as existential values, rather than forms of discourse dominated by dogmatic exactness or sheer rationality. In this respect esotericism becomes a form of "marginal religion", very close to what Wouter J. Hanegraaff understands by his term of "repudiated knowledge".

Finally, the last dimension enumerated by Faivre narrows down the domain, perhaps too much in our opinion, towards a fundamental landmark, shared by many

\footnotetext{
${ }^{2}$ Antoine Faivre, Căi de acces la esoterismul occidental. Vol. II. Teozofie, imaginaţie, Tradiţie [An Itinerary to the Western Esotericism. 2nd vol.: Theosophy, Imagination, Tradition]. Translated by Ion Doru Brana, Bucharest, Nemira, 2008, p. 21.

${ }^{3}$ Ibidem, pp. 10-13.
} 
forms of esotericism (in a long historical row from Ficino up to Guénon), namely "the quest for a 'Primordial Tradition"”. Due to Guénon's unchallenged prestige in the epoch, associated to the international success of his theories, this is precisely the dimension which dominates the interest in esotericism in the Romanian cultural life during the interwar period (1919-1938). Perennialism, as it is usually called, starts from the assumption that wisdom is the outcome of an ancient, primordial Tradition, accessible only to the initiates through the given religions, which are only partial remnants of it. In his seminal Guénon ou le renversement des clartés, Xavier Accart analyses Guénon's influence on a tremendous number of European first-hand intellectuals (Queneau, Artaud, Gide, Paulhan, Daumal, Bosco, Drieu La Rochelle, Pauwels, Daniel Halévy, Léon Daudet, Jean Grenier, Simone Weil), while Claudio Mutti's Guénon in Romania [Guénon în România] detects the Master's influence on the most prominent Romanian intellectuals of the period (Mircea Eliade, Mihail Vîlsan, Vasile Lovinescu, Anton Dumitriu, Mihail Avramescu).

But let us stick to Antoine Faivre's categories for a while. Being aware that all his outlined "dimensions" are more or less vulnerable or shaky, but also convinced that esotericism has to be scrutinized through the lenses of a historical and critical approach, Faivre defines esotericism as a "set of complex particular historical tendencies"4 having precise chronological relationships and connections, delineated geographically by a Western civilization consciously "permeated" by specific Oriental traditions and ideas. The time coincides with the emergence of a heterogeneous Modernity experienced by the Renaissance, when numerous cultural sediments borrowed from the antiquity are restructured again into a new type of epistemological mould. It is the time of the so-called philosophia perennis, a particular type of hermeneutics based on the belief in the existence of the Great Sages of the past and in their spiritual teachings transmitted especially by oral means. The new trend of knowledge includes the neo-Alexandrian Hermetism, the Christian Kabbalah, the philosophia occulta, the Rosicrucian belief, the Christian theosophy and the new occultism of the $19^{\text {th }}$ century. According to Antoine Faivre, the quest for the perennial philosophy provides, in the first centuries of early Modernism, "the autonomy of an extra-theological discourse related to cosmology, and the idea of a possible revelation inside the Revelation"s. This means a personal, inner revelation inside the outer revelation of the Christianity, both of them conceived as complementary to the official study of religions.

By scrutinizing the texture of the esoteric discourses, Antoine Faivre ${ }^{6}$ identifies two series of characteristics which belong to Western esotericism seen as a field of study. In the first, considered to be the essential pool, he places four intrinsic characteristics: the idea of universal correspondences (all the symbolical, visible or

\footnotetext{
${ }^{4}$ Ibidem, p. 13.

${ }^{5}$ Ibidem, p. 16.

${ }^{6}$ Ibidem, pp. 19-23, 46-50.
} 
invisible correspondences of the universe considered real), the idea of nature seen as a living being (the Cosmos seen as a network of incessant, intense relationships), the importance of mediation and imagination (as complementary tools in the process of deciphering the world), as well as the experience of transmutation, according to which life is a process of expanding spiritual experiment. The second, subsidiary pool contains frequently encountered, but not obligatory features. They include: the practice of concordance (by which different traditions might share one or multiple characteristics), and the practice of transmission, based on the assumption that a secret tradition is relayed through peculiar "channels of transmission" such as, for instance, the connection between a Master and his disciple. By combining all these characteristics, the author asserts, we will eventually understand Western esotericism as a peculiar mind structure, or "form of thinking" (forma mentis). Moreover, due to their explicit non-dogmatic flexibility, the five characteristics can function as "containers for different types of imaginary things" , hence the consequent need for an interdisciplinary approach to the domain.

In his turn, Pierre A. Riffard ${ }^{8}$ suggests a completely different perspective, based on a special type of "esoterology", conceived of as a kind of global and synthetic wisdom, able to compare and interpret everything in an effort to identify laws and frames, structures and functions which determine the general status of cultural secrecy. Riffard ${ }^{9}$ subsequently identifies a form of ecstatic esotericism whose essence is life engaged in an effort to imbue the conscience with an energetic mood of frenzy (the best example is the Dionysian kind), a form of metaphysical esotericism devoted to philosophy and to ways of thinking whose origins can be identified precisely in the past (for instance, the Pythagorean tradition), a form of operational esotericism, the occult practice nurtured by the idea that the universe is something which can be improved (as the Freemasons do), and a form of symbolic esotericism, a domain of liminality suspended between what is real and what is spiritual and whose essence is imagining. There is no esotericism without images, Pierre A. Riffard sharply asserts ${ }^{10}$.

By focusing his effort on systematising the domain of secrecy and esotericism, Pierre A. Riffard ${ }^{11}$ identifies eight invariants, each of them with a large number of subclasses. These eight invariants are: the author's impersonality, the contrast between the profane and the initiated, the gift of subtlety, the belief in analogies, the science of correspondences, the power of numbers, the occult arts and sciences, as well as the practice of initiation. By confronting Pierre A. Riffard's model,

\footnotetext{
${ }^{7}$ Ibidem, p. 22.

${ }^{8}$ Pierre A. Riffard, L'Ésotérisme, Qu'est-ce que l'ésotérisme? Anthologie de l'ésotérisme occidental, Paris, Éditions Robert Laffont, 1990, p. 54.

${ }^{9}$ Ibidem, pp. 216-223.

${ }^{10}$ Ibidem, p. 226.

${ }^{11}$ Ibidem, p. 310.
} 
Antoine Faivre ${ }^{12}$ challenges his universalistic assumption and the lack of historicity, but praises Riffard's invitation to set up a comparative study of esotericism.

According to Wouter J. Hanegraaff, quoted by Faivre ${ }^{13}$, the scholar of esotericism must work as an archaeologist in order to trace the evolution of certain ideas, not guided by the assumption that these ideas share some sort of transhistorical or meta-historical common ground, but with the intention of explaining why several people absorb and reshape ideas from the past, while others are apparently not capable of doing so. The scholar must also explain the spatial migration of these ideas, both among different forms or expression of the esoteric wisdom, and within the arts, literatures or the field of ideas.

Precision is nevertheless a must, because, when dealing with ideas, the Dutch scholar does not see them as ideologies, but as forms of the imaginary, and in this respect his attitude coincides with Antoine Faivre's. In a paper published in 2007 in a volume entitled Political Encounters ${ }^{14}$, Wouter J. Hanegraaf analyses the selective affinity between the scholarly approaches of Western esotericism and the study of images, also dedicating some generous space to Faivre's appraisal in the first part of his text. His analysis focuses on the compatibility between the French author's perspective on esotericism and the study of the imaginary. It deals with the prevalence of the symbolic and mythical dimension over rational doctrine and also underlies the fact that there is a measure of similitude between Faivre's ideas and the approach promoted by the scholars meeting at the Eranos intellectual debates, where one of the invitees is Mircea Eliade himself. The Dutch scholar also notices that Western culture has always had an iconoclastic bias by favouring a kind of abstract and ubiquitous God engaged in unequal competition with His pagan counterparts represented by statues and images. Another idea is related to the practice of cultural suspicion, Hanegraaf suggesting that the increasingly powerful domain of the imaginary in European civilization has generated a gradual process of rejection, with esotericism itself as one of the victims, proclaimed to be a field full of traps and dangers.

Furthermore, Wouter J. Hanegraaf considers that Western scholarly esotericism represents the historical outcome of a so-called "Grand Polemical Narrative", a process through which the Western culture has built, over the centuries, its own identity by freely combining elements belonging either to cosmotheism or monotheism. If we accept - the Dutch scholar also asserts - that personal and cultural self-identity are constructed by generating narratives related to who, what and how we intend to be, we shall also have to accept that these narratives become

\footnotetext{
${ }^{12}$ Antoine Faivre, Căi de acces la esoterismul occidental, pp. 51-52.

${ }^{13}$ See Ibidem, p. 59

${ }^{14}$ Wouter J. Hanegraaff, "The Trouble with Images: Anti-Image Polemics and Western Esotericism", in Olav Hammer and Kocku von Stuckard (eds.), Polemical Encounters. Esoteric Discource and Its Others, Leiden-Boston, Brill Academie Publishers, 2007, pp. 107-136.
} 
what they are only by constructing a counter-narrative, a negative mirror image or "significant Other, in which we project what we do not want to be. In the collective imaginary of the $18^{\text {th }}$ century, esotericism played the very role of the "significant Other" and was therefore treated with cautiousness, hatred or suspicion.

There also exists - Wouter J. Hanegraaf says ${ }^{15}$ - a sharp distinction between the way in which the esoteric devotee and esotericism are presented in the popular polemical imagination and the way they really are when we scrutinise them in a critical, scientific way. In order to demonstrate his idea, and following the urge for necessary historical corrections, the Dutch scholar deconstructs several rejection mechanisms within the "Grand Polemical Narrative", by drawing a further distinction between "mnemohistory" (history filtered through the informal channels of the collective imagination) and historiography, the scientific, objective approach to the field. Since esotericism appears as a construct which is formed primarily inside the channels of the collective imagination, an analysis of the imaginary involved in the "Grand Polemical Narrative" becomes essential.

In Kocku von Stuckrad's view ${ }^{16}$, the problem of esoteric identity in Europe has always been permeated by tension, because esotericism has always claimed to offer a higher type of knowledge than any other epistemological discourse. The German scholar says that, during its evolution, the European history of culture has always mixed rejection and fascination into the collective perception of esotericism ${ }^{17}$ precisely because esotericism has elevated secrecy to the level of a privileged social value ${ }^{18}$, also claiming that there is only one kind of "perfect knowledge", namely esoteric knowledge ${ }^{19}$. The Swedish scholar Henrik Bogdan ${ }^{20}$ adds a further layer to this latest dimension by saying that esotericism can be conceived as a peculiar and defining Western concept of spirituality, based, on the one hand, on the individuals' quest for personal, not collective spiritual freedom, and, on the other, on Gnosis, that is on an attitude that establishes a direct connection between the individual and the divine dimension of existence.

Following Antoine Faivre's considerations, Gerald Messadié defines esotericism as a "mental attitude" 21 , but he approaches it from a broader perspective than his predecessors, both chronologically (by formulas like: "esotericism is as old as the relationship between the human and the divine" ${ }^{22}$ ) and

\footnotetext{
${ }^{15}$ Wouter J. Hanegraaff, The Trouble with Images, p. 111.

${ }^{16}$ Kocku von Stuckrad, Locations of Knowledge in Medieval and Early Modern Europe. Esoteric Discourse and Western Identities, Leiden-Boston, Brill Academic Publishers, 2010, pp. 60-64.

${ }^{17}$ Ibidem, p. 54.

${ }^{18}$ Ibidem, pp. 54-59.

${ }^{19}$ Ibidem, pp. 59-67.

${ }^{20}$ Henrik Bogdan, Western Esotericism and Rituals of Initiation, Albany, State University of New York Press, 2007, p. 5.

${ }^{21}$ Gerald Messadié, Patruzeci de secole de esoterism [Forty Centuries of Esotericism]. Translated by Claudia Dumitru, Bucharest, Nemira, 2008, p. 6.

22 Ibidem, p. 7.
} 
from the perspective of its manifestations. Thus, the French author promotes a premeditatedly eclectic and arbitrary selection, derived from a so-called culture of fraternisation, which explains why different esoteric doctrines are actually similar to one another. Messadié ends by saying that the knowledge of secrecy is an "innate structure and function of the mind" 23 .

Way beyond any polemic or battle of concepts, the European academic destiny of esotericism has suffered substantial relocations if we take into account the backlash of heresiology, which exiled esotericism to the damned and repudiated margins of knowledge. The metamorphosis of a formerly condemned domain into an openly desirable academic field, full of lucrative scientific approaches, is due to the group of scholars at the Eranos meetings (Carl Gustav Jung, Mircea Eliade ${ }^{24}$, Henry Corbin, Gilbert Durand, Joseph Campbell) whose dedication to the history of religious ideas re-oriented the researchers' interest to esotericism, a challenging, off-mainstream reservoir of knowledge that can prove inspirational to our "disenchanted" (Max Weber dixit) world. Paying tribute to their role, Antoine Faivre nevertheless distances himself from the Eranos Masters' apologetic approach to esotericism, as well as from their tendency to promote trans-historical discourses, believing that the scholarly study of esotericism must rely on strict facts existing in the historical and critical approach to the domain.

The trust placed in initiation and in the priority of symbolic wisdom provides the basis for Radu Cernătescu's Literatura luciferică of 2010 [The Luciferian Literature], the most challenging Romanian approach concerning the relationship between the occult and literature, although a great deal of secret institutional affiliations is not documented by the author, being promoted on more or less speculative grounds. The author explains the Romanian writers' inclination for the domain of occultism and secrecy by their wish to reach the upper limit of imagination, as well as by a psychological ingredient called "Luciferian vanity" 25 , manifested as a desire to belong to a spiritual elite, and by the wish to acquire and share a privileged form of symbolic wisdom, inaccessible to the masses.

Starting from such an assumption, Radu Cernătescu's literary history is converted into a history of subterraneous contents, where literary texts are

\footnotetext{
${ }^{23}$ Ibidem, p. 16.

${ }^{24}$ The conclusion of a paper written by Eliade, entitled The Occult and the Modern World, presented at a conference dedicated to Freud's commemoration in 1974 is interesting: „Thus, to sum up, contemporary scholarship has disclosed the consistent religious meaning and the cultural function of a great number of occlt practices, beliefs and theories, recorded in many civilizations, European and non-European alike, and at all levels of culture, from folk rituals - such as magic and witchcraft- to the most learned and elaborate secret techniques and esoteric speculations: alchemy, Yoga, Tantrism, Gnosticism, Renaissance Hermeticism, and secret societies and Masonic lodges of the Enlightenment period." (Mircea Eliade, Occultism, Witchcraft, and Cultural Fashions. Essays in Comparative Religions, chapter IV, Chicago, The University of Chicago Press, 1974, p. 58).

${ }_{25}$ Radu Cernătescu, Literatura luciferică. O istorie ocultă a literaturii române [The Luciferian Literature. An Occult History of the Romanian Literature], Bucharest, Cartea Românească, 2010, p. 7.
} 
conceived either as vehicles for hidden archetypes and symbols, or as subtle containers for a type of long- forgotten, occult wisdom. It is a type of literary history which cannot be deciphered in the traditional way of the usual literary histories accredited by the canons, first of all because aestheticism is downgraded or openly driven out of the context. Thus, G. Călinescu's massive history from 1941, the landmark of all Romanian literary histories, becomes Cernătescu's preferred counter-example, as it has no consideration for the occult aspects of Romanian literature, based on initiation. Radu Cernătescu argues that a more desirable alternative would be a history of the Romanian literature

centered not on the text, but on its metaphysical context, not on aesthetic decoding, but on the multi-sided infrastructure of the message, a trans-disciplinary approach able to exhume the common denominator of the great works, the everlasting archaic subtext of themes, symbols and codes that channel the transcendence which eventually provides the identity and greatness of a given culture ${ }^{26}$.

The project is full of ambition but unable to avoid all the risks involved, the most obvious of them being that of over-interpretation. The hasty historian starts from the assumption that the multi-layered writings of the authors included in his book share a common "mystogenetic" matrix ${ }^{27}$ whose presence explains the validity of the works and the reason why they are still read. Distancing himself from G. Călinescu's comprehensive literary history, which is systematically condemned for its simplicity, Radu Cernătescu surprisingly reconstructs, for instance, the occult layers of G. Coşbuc's poems and their initiatory, Freemason motivation, although it's difficult to believe that the poet created his cadenced patriotic verses by referring to an occult, difficult-to-understand, non-popular imaginary. Mircea Eliade, Mihail Sadoveanu, Vasile Voiculescu, Mihai Eminescu and, rather surprisingly, G. Călinescu as a novelist suffer the similar fate of overinterpretation.

Diachronically, Radu Cernătescu's literary history starts with Johann Heinrich Alsted and Gabriel Bethlen (in a chapter entitled "Romanian Rosicrucian Traditions"), but it rapidly turns into a book obsessed with Freemasonry, a fixation which is also responsible for the great majority of over-interpretations scattered throughout the work. For instance, in a chapter entitled "Pre-Romanticism - a mythology of the Romanian spiritual mountaineering", all references to mountains or high places are explained by the authors' Freemason engagement and by some sort of hidden Rosicrucian devotion, which is far from being true or at least satisfactory if we rely on verifiable documents and facts.

Another ambitious synthetic Romanian work concerning the secret aspects of the Romanian history of literature belongs to Cornel Ungureanu, an accomplished literary historian showing a real documentary interest in writers with a secret

\footnotetext{
${ }^{26}$ Ibidem, p. 11.

${ }^{27}$ Ibidem, pp. 11-12.
} 
identity. Entitled $O$ istorie secretă a literaturii române [A Secret History of the Romanian Literature], Ungureanu's work is fuelled by the desire to provide an alternative domestic literary history by retrieving, from the thick archival dust, a special cultural and literary domain which has suffered a process of deliberate tabooing under the political and ideological censorship of the Communist era. In order to achieve his task, Ungureanu relies on the methods of literary geography and geopolitics, finally assembling an intricate mixture of socio-historical contextual analyses, while he also intentionally or unintentionally omits biographical details in order to assert the existence of a "secret depository of the Romanian literature" 28 .

In a strenuous effort to explore it, the author sweeps together data taken from the secret files of the authors (kept, some of them, in the archives of the Romanian Secret Police) and from literary works lost in oblivion, while he also calls back to life those privileged moments when several Romanian authors were directly connected with theosophy or esotericism. For instance, by writing an Intermezzo dedicated to Gala Galaction (a prose writer and translator of the Bible), Cornel Ungureanu inserts an episode recalling Josephin Peladan's 1898 visit to Bucharest as a guest of Alexandru Bogdan-Pitești. The literary description of the visit is full of esoteric suggestions, because - as Ungureanu says -

when Sar Peladan deliverered his conference at the Athenaeum dressed in an Indian outfit, the youngster [Gala Galaction] was driven into ecstasy. He was charmed, fascinated and ransacked by the handsome and famous speaker. He was terribly impressed by Bogdan-Pitești's invitee, the newly converted Josephin Peladan. But Bogdan-Pitești, a man who has just returned from Paris, a rebel against the traditional norms, was he not himself one of the initiated? [...] Wasn't he a paradoxical individual himself, having created, in a world dominated by traditions, an underground which would nurture a long series of fundamental authors belonging to the «new literature», like Galaction, Arghezi, Mateiu Caragiale and Ion Vinea?29

The collection of the more or less unknown, or long-ignored, details gathered in Cornel Ungureanu's history require a flexible and associative analysis, especially when we come across ideological shifts or sensationalist theories related to different secret societies. Some of these aspects are visible in the text dedicated to Mihai Eminescu, the Romanian national poet, whose creation is analysed through the lenses of a spiritual geography, while the author does not fail to mention the "traditional" wisdom hidden well beneath Eminescu's poetry and the hypothesis that it could be the outcome of an initiatory affiliation.

The book also includes a chapter entitled "Generația ezoterică" ["The Esoteric Generation"], whose protagonists are Marcel Avramescu (with a vivid picture

\footnotetext{
${ }^{28}$ Cornel Ungureanu, $O$ istorie secretă a literaturii române, ediția a II-a revăzută și adăugită $[A$ Secret History of the Romanian Literature. $2^{\text {nd }}$, revised ed.], Bucharest, Tracus Arte, 2016, p. 78.

${ }^{29}$ Ibidem, p. 68.
} 
including memories related to his magnetic personality, his initiation into Guénon, the publication of MEMRA, the very first Romanian openly esoteric literary journal, and the presentation of his avant-garde texts) and Vasile Lovinescu. The great absentee from the chapter might be Mircea Eliade himself, who is nevertheless the protagonist of several further approaches dedicated to his esotericism, conceived as the primeval layer of his thinking. To sum up - Cornel Ungureanu states -, "in Eliade's world, created by repeated dismissals and taboos, Evola and Guénon must be treated cautiously." 30 Nevertheless, the author cannot finish his assumptions without enthusiastically quoting other, less cautious works, like Marcel Tolcea's Eliade, ezotericul (The Esoteric Eliade), a controversial book published in 2002 which, however, still has its adherents.

\section{BIBLIOGRAPHY}

BOGDAN, Henrik, Western Esotericism and Rituals of Initiation, Albany, State University of New York Press, 2007.

CERNĂTESCU, Radu, Literatura luciferică. O istorie ocultă a literaturii române [The Luciferian Literature. An Occult History of the Romanian Literature], Bucharest, Cartea Românească, 2010.

ELIADE, Mircea, Occultism, Witchcraft, and Cultural Fashions. Essays in Comparative Religions, chapter IV, Chicago, The University of Chicago Press, 1974.

FAIVRE, Antoine, Căi de acces la esoterismul occidental. Vol. II. Teozofie, imaginaţie, Tradiţie [An Itinerary to the Western Esotericism. 2nd vol.: Theosophy, Imagination, Tradition]. Translated by Ion Doru Brana,. Bucharest, Nemira, 2008.

HANEGRAAFF, Wouter J., "The Trouble with Images: Anti-Image Polemics and Western Esotericism", in Olav Hammer and Kocku von Stuckard (eds.), Polemical Encounters. Esoteric Discource and Its Others, Leiden-Boston, Brill Academie Publishers, 2007, pp. 107-136.

LAGRANGE, Pierre, Renaissance d'un ésotérisme occidental (1945-1960): L'ésotérisme contemporain et ses lecteurs : Entre savoirs, croyances et fictions [en ligne], Paris, Éditions de la Bibliothèque publique d'information, 2005.

MESSADIÉ, Gerald, Patruzeci de secole de esoterism [Forty Centuries of Esotericism]. Translated by Claudia Dumitru, Bucharest, Nemira, 2008.

RIFFARD, Pierre A. L'Ésotérisme, Qu'est-ce que l'ésotérisme?. Anthologie de l'ésotérisme occidental, Paris, Éditions Robert Laffont, 1990.

UNGUREANU, Cornel, $O$ istorie secretă a literaturii române, ediția a II-a revăzută și adăugită $[A$ Secret History of the Romanian Literature. $2^{\text {nd }}$, revised ed.], Bucharest, Tracus Arte, 2016.

VON STUCKRAD, Kocku, Locations of Knowledge in Medieval and Early Modern Europe. Esoteric Discourse and Western Identities, Leiden-Boston, Brill Academic Publishers, 2010.

${ }^{30}$ Ibidem, p. 286. 


\title{
ESOTERICISM AND SECRECY IN ALTERNATIVE LITERARY HISTORIES
}

\author{
(Abstract)
}

Following the end of WW2, a literary trend called "scholarly esotericism" ("ésotérisme savant") emerged in the writings of the French historians of culture and literature, designating the tendency to identify and decrypt, in a systematic and objective approach, the sub-textual, esoteric and secret references in the literary texts. Two important landmarks of this sub-domain of the literary history are Robert Amadou and Robert Kanters' Anthologie littéraire de l'occultisme and Xavier Accart's Guénon ou le renversement des clartés, dedicated to Guénon's influence on the French history of literature and of ideas from 1920 to 1970, that is well beyond the Master's death in 1951. The final aim of these specific intellectual approaches is to construct an alternative, so-called secret literary history, already translated into the Romanian literary studies by two intriguing challenges to the mainstream aesthetic literary history, proposed by Radu Cernătescu (Literatura luciferică [The Luciferian Literature]) and Cornel Ungureanu ( $O$ istorie secretă a literaturii române $[A$ Secret History of the Romanian Literature]). The paper intends to analyse the methodology and inner life of these specific literary histories, by relating them to the classical, official histories of literature, as well as to the main patterns of the national and international collective identity.

Keywords: literary history, histoire littéraire, esotericism, secrecy, Romanian literature, cultural identity.

\section{ESOTERISM ȘI DOCTRINE SECRETE ÎN ISTORIILE LITERARE ALTERNATIVE \\ (Rezumat)}

După sfârşitul celui de-al Doilea Război Mondial, și-a făcut apariția în scrierile istoricilor francezi ai culturii și literaturii un curent ideatic numit „esoterism academic” („ésotérisme savant”), care își propunea să identifice și să decripteze, într-un mod sistematic și obiectiv, referințele subtextuale, esoterice și sibilinice ale textelor literare. Principalele repere exegetice ale acestui subdomeniu de istorie literară sunt Anthologie littéraire de l'occultisme, semnată de Robert Amadou și Robert Kanters, respectiv Guénon ou le renversement des clartés, lucrarea lui Xavier Accart dedicată influenței exercitate de către Guénon asupra istoriei literaturii și a ideilor din Franța perioadei 19201970, adică și dincolo de trecerea în neființă a Maestrului în 1951. Scopul acestor abordări intelectuale specifice îl reprezintă construirea unei istorii literare alternative, așa-zis secrete, care translează în două incitante studii literare românești - Literatura luciferică a lui Radu Cernătescu și $O$ istorie secretă a literaturii române a lui Cornel Ungureanu -, menite să concureze istoria literară esteto-centrică. Studiul de față își propune să analizeze metodologia și morfosintaxa internă a acestor istorii literare alternative, punându-le în relație, pe de o parte, cu istoriile literare canonice şi, pe de altă parte, cu structurile dominante ale identității colective naționale și transnaționale.

Cuvinte-cheie: istoria literaturii, esoterism, doctrine secrete, literatură română, identitate culturală. 